\title{
Effects of tannins and Monensin in a feedlot diet on in vitro ruminal fermentation ${ }^{1}$
}

\section{Efeitos de taninos e monensina em uma ração para ovinos em confinamento sobre os parâmetros da fermentação ruminal in vitro}

\author{
Hariany Ferreira Martello²; Nelcino Francisco de Paula ${ }^{3 *}$; Bruna Gomes Macedo²; \\ Joanis Tilemahos Zervoudakis ${ }^{4}$; Danielle Dias Brutti ${ }^{5}$; Perivaldo Carvalho ${ }^{6}$, \\ Ronyatta Weich Teobaldo ${ }^{7}$; Luciano da Silva Cabral ${ }^{3}$; Mozart Alves Fonseca ${ }^{8}$
}

\begin{abstract}
The objective of this study was to evaluate the effects of tannins versus Monensin on in vitro ruminal fermentation of a feedlot diet. The treatments were: control (no additives); low tannin ( $2 \mathrm{mg} \mathrm{g} \mathrm{DM}^{-}$ $\left.{ }^{1}\right)$; medium tannin $\left(4 \mathrm{mg} \mathrm{g} \mathrm{DM}^{-1}\right)$, high tannin $\left(6 \mathrm{mg} \mathrm{g} \mathrm{DM}^{-1}\right)$, and Monensin $\left(0.02 \mathrm{mg} \mathrm{g} \mathrm{DM}^{-1}\right)$. The substrate was a feedlot diet composed by hay and concentrate (15:85 w/w; DM basis). Ruminal fluid was obtained from three rumen-cannulated male Santa Inês sheep. In vitro incubations were carried out during four consecutive weeks (run). Gas production (GP) was recorded at 1, 2, 3, 4, 5, 6, 8, 10, $12,18,24,30,36,42,48,60,72,84$, and $96 \mathrm{~h}$ of incubation. At 48 and $96 \mathrm{~h}$, two bottles per treatment were withdrawn to measure $\mathrm{pH}$, ammonia concentration $\left(\mathrm{NH}_{3}\right)$, volatile fatty acid (VFA), in vitro dry matter digestibility (IVDMD), and in vitro neutral detergent fiber digestibility (IVNDFD). Addition of tannin or Monensin did not affect $(\mathrm{P}>0.05)$ the kinetics parameters. Tannin supplementation reduced $(\mathrm{P}<0.05)$ the GP at $24 \mathrm{~h}$ compared to Monensin. Addition of Monensin decreased $(\mathrm{P}<0.05)$ IVDMD at $96 \mathrm{~h}$ and IVNDFD at 48 and $96 \mathrm{~h}$ compared to the control. The IVNDFD was lower $(\mathrm{P}<0.05)$ with Monensin than with tannin at 48 and $96 \mathrm{~h}$. The $\mathrm{NH}_{3}$ was lower $(\mathrm{P}<0.05)$ with tannin compared with Monensin. By increasing tannin dosage, $\mathrm{NH}_{3}$ levels changed quadratically $(\mathrm{P}<0.05)$ The inclusion of tannin in vitro reduced the $\mathrm{NH}_{3}$ concentration considerably when used in low dose.
\end{abstract}

Key words: Additive. Beef cattle. Digestibility. Metabolism. Rumen.

\footnotetext{
1 Parte da Dissertação de Mestrado da primeira autora, Programa de Pós-Graduação em Ciência Animal, Universidade Federal de Mato Grosso, UFMT.

2 Discentes, Curso de Mestrado, Programa de Pós-Graduação em Ciência Animal, UFMT, Cuiabá, MT, Brasil. E-mail: harianyferreira@hotmail.com; bruna-macedoo@live.com

3 Profs. Drs., Faculdade de Agronomia e Zootecnia, Departamento de Zootecnia e Extensão Rural, UFMT, Cuiabá, MT, Brasil. E-mail: nelcinodepaula@hotmail.com; lucianoufmt@gmail.com

4 Prof. Dr., Faculdade de Medicina Veterinária, UFMT, Cuiabá, MT, Brasil. E-mail: joanis@ufmt.br

5 Discente, Curso de Doutorado, Programa de Pós-Graduação em Zootecnia, Universidade Federal do Rio Grande do Sul, UFRGS, Porto Alegre, RS, Brasil. E-mail: dani_brutti@hotmail.com

6 Discente, Curso de Doutorado, Programa de Pós-Graduação em Agricultura Tropical, UFMT, Cuiabá, MT, Brasil. E-mail: perivaldo_carvalho@hotmail.com

7 Discente, Curso de Doutorado, Programa de Pós-Graduação em Zootecnia, Universidade Estadual Paulista Júlio de Mesquita, UNESP, Jaboticabal, SP, Brasil. E-mail: ronyattaweich@hotmail.com

8 Prof. Dr., Department of Agriculture, Nutrition \& Veterinary Sciences, University of Nevada, Reno, Nevada, United States. E-mail:mfonseca@cabnr.unr.edu

* Author for correspondence
} 


\section{Resumo}

O objetivo com este estudo foi avaliar os efeitos de taninos versus monensina sobre a fermentação ruminal in vitro de uma ração para ovinos em confinamento. Os tratamentos foram: controle (sem a inclusão de aditivos); baixa dose de tanino $\left(2 \mathrm{mg} \mathrm{g} \mathrm{MS}^{-1}\right)$; média dose de tanino $\left(4 \mathrm{mg} \mathrm{g} \mathrm{MS}^{-1}\right)$, alta dose de tanino (6 $\left.\mathrm{mg} \mathrm{g} \mathrm{MS}^{-1}\right)$, e monensina $\left(0,02 \mathrm{mg} \mathrm{g} \mathrm{MS}^{-1}\right)$. O substrato utilizado foi uma ração para ovinos em confinamento composta por feno e concentrado (15:85 w/w; base da MS). O fluido ruminal foi obtido de três ovinos Santa Inês, machos não castrados, com cânula ruminal. As incubações in vitro foram realizadas em quatro semanas consecutivas (uma incubação por semana). A produção de gás (PG) foi mensurada nos tempos 1, 2, 3, 4, 5, 6, 8, 10, 12, 18, 24, 30, 36, 42, 48, 60, 72, 84 e 96 horas de incubação. Nos tempos de 48 e 96 horas, dois frascos/tratamento foram retirados para mensurar $\mathrm{pH}$, concentração de amônia $\left(\mathrm{NH}_{3}\right)$ ácidos graxos voláteis ( $\left.\mathrm{AGV}\right)$, digestibilidade in vitro da matéria seca (DIVMS) e digestibilidade in vitro da fibra em detergente neutro (DIVFDN). A adição de tanino ou monensina não afetaram $(\mathrm{P}>0,05)$ os parâmetros cinéticos. A suplementação de tanino reduz $(\mathrm{P}<$ $0,05)$ a PG em 24 horas de incubação comparado com a monensina. A inclusão de monensina reduz (P $<0,05)$ a DIVMS em 96 horas e a DIVFDN em 48 e 96 horas comparada ao controle. A DIVFDN foi menor $(\mathrm{P}<0,05)$ com monensina que com tanino em 48 e 96 horas. $\mathrm{A} \mathrm{NH}_{3}$ foi menor $(\mathrm{P}<0,05)$ com tanino comparado à monensina. Aumentando a dose de tanino, a $\mathrm{NH}_{3}$ altera de forma quadrática $(\mathrm{P}<$ $0,05)$ A inclusão de tanino reduz consideravelmente as concentrações in vitro de $\mathrm{NH}_{3}$ quando usado em baixas doses.

Palavras-chave: Aditivo. Bovinos de corte. Digestibilidade. Metabolismo. Rúmen.

\section{Introduction}

The ionophore Monensin is the most commonly used feed additive in feedlot diets to improve the efficiency of ruminal fermentation (TEDESCHI et al., 2011). Effects include a decrease in the acetate: propionate ratio, improvement of feed efficiency, reduction of rumen deamination, decreases in $\mathrm{CH}_{4}$ production, and the risks of metabolic diseases (DINIUS et al., 1976this research sought to increase the knowledge around $\$ \backslash \$$ nthe real-life experience of Jatropha farming in the southern India\$ $\backslash$ \$nstates of Tamil Nadu and Andhra Pradesh. Launched as an alternative for $\$ \backslash \$$ ndiesel in India, Jatropha has been promoted as a non-edible plant that $\$ \backslash \$$ ncould grow on poor soils, yield oil-rich seeds for production of $\$ \backslash$ \$nbio-diesel, and not compete directly with food production. Through\$ $\$$ \$ ninterviews with the farmers, information was gathered regarding their $\$ \backslash \$$ nsocio-economic situation, the implementation and performance of their\$ $\backslash \$$ nJatropha plantations, and their reasons for continuing or discontinuing $\$ \backslash \$$ nJatropha cultivation. Results reveal that $82\{\%\}$ of the farmers had\$ $\mid \backslash$ nsubstituted former cropland for their Jatropha cultivation. By 2010,\$\\$n85\{\%\} ( $\mathrm{n}$ = 90; RUSSELL; STROBEL, 1989). Despite advantageous benefits of Monensin, growing public concerns over chemical residues in animal-derived foods, threats of antibiotic-resistant bacteria and an outright ban by the European Union (TEDESCHI et al., 2011), the animal feed industry have renewed their interest in exploring the use of safer alternatives in substitution of chemical feed additives historically used for ruminant livestock feeding.

Several natural alternatives such as plants, plant extracts, and secondary metabolites (e.g. tannins, saponins, and essential oils) with antibioticlike action potential have received considerable attention as natural ways to manipulate ruminal fermentation (MEZZOMO et al., 2011ruminal and total digestibility, ruminal digestion rate, protein efficiency, and microbial efficiency in beef steers fed high concentrate diet ( $87 \%$ of DM; TEDESCHI et al., 2011).

Tannins are secondary plant products and consist of water-soluble polyphenolic compounds with high molecular weight, classified as either condensed or 
hydrolysable. Some studies suggest that tannins may improve the use of the dietetic protein without impairing feed intake or carbohydrate digestibility because their phenolic hydroxyl group can bind to the protein or amino acids, protecting from the ruminal tract and therefore prevents enzymatic hydrolysis (WAGHORN et al., 1987). The complexes are presumed to dissociate during the passage through the more acidic environment of the abomasum or in the alkaline environment of the small intestine (MCMAHON et al., 1999). Condensed tannins may also bind directly to hydrolytic enzymes, rendering them catalytically inactive (MAKKAR et al., 1998). In addition, tannins have a potentially wide range of effects on ruminal fermentation, such as the prevention of metabolic disorders (CIESLAK et al., 2012)ammonia concentration $(\mathrm{P}<0.001$ and the mitigation of rumen methane emissions (BUENO et al., 2015)zebu beef cattle (Bos taurus indicus. However, these effects on animal metabolism depend on the dose, the substrate, and the type of tannin (GETACHEW et al., 2008).

Therefore, the objective this study was to evaluate the effects of the addition of Monensin and increasing levels of tannins on the kinetics of gas production, dry matter and neutral detergent fiber digestibility, volatile fatty acids concentrations, and ammonia concentrations in feedlot diets.

\section{Materials and Methods}

\section{Animal donors of rumen fluids}

The experiment was approved by the Institutional Committee for Ethics in the Use of Animals of the UFMT-Cuiabá (244/2015). Three rumen-cannulated male Santa Inês sheep $(60 \pm 3 \mathrm{~kg}$ $\mathrm{BW}$ ), fed a total mixed ration (TMR) ration with a 40:60 hay: concentrate ratio, previously adapted for 30 days, were used as donors of rumen fluids. The animals were kept in individual sheltered pens equipped with water and feed troughs.

\section{Experimental design and in vitro rumen fermentation}

In vitro incubations were carried out over four consecutive weeks (runs). The substrate consisted of a feedlot ration with $15 \%$ of Panicum maximum cv. Massai hay, $60 \%$ ground corn, $10.5 \%$ soybean meal, $11.8 \%$ soybean hulls, $0.7 \%$ urea, and $2 \%$ mineral mixture (Table 1).

Table 1. Ingredients and chemical composition of the substrate (DM basis).

\begin{tabular}{lc}
\hline Item, \% DM & Substrate diet \\
\hline Ingredients $\left(\mathrm{g} \mathrm{kg}^{-1}\right)$ & \\
Grass hay $^{\mathrm{a}}$ & 148.1 \\
Ground corn & 606.3 \\
Soybean meal & 104.9 \\
Soy hulls & 116.5 \\
Urea & 6.21 \\
Mineral mixture & 17.7 \\
Chemical composition $\left(\mathrm{g} \mathrm{kg}^{-1}\right.$, DM basis) & \\
DM & 879.6 \\
CP & 139.8 \\
NDF & 297.7 \\
\hline
\end{tabular}

${ }^{a}$ Panicum maximum cv. Massai hay. 
A commercial blend of tannin ( $70 \%$ hydrolysable and condensed tannins; Silvafeed-Bypro ${ }^{\circ}$, Silvateam-Inudor S.A., Argentina) was used. Experimental treatments were as follows: control (no additives); low tannin (2 $\left.\mathrm{mg} \mathrm{g} \mathrm{DM}^{-1}\right)$; medium tannin (4 mg g DM$\left.{ }^{-1}\right)$, high tannin (6 $\left.\mathrm{mg} \mathrm{g} \mathrm{DM}^{-1}\right)$, and Monensin (0.02 $\mathrm{mg} \mathrm{g} \mathrm{DM}^{-1}$; Rumensin ${ }^{\circledR E l a n c o}$, $20 \%$, USA). The experimental doses of tannin were above and below the manufacturer's recommendation.

To each $120-\mathrm{mL}$ serum bottles, $0.5 \mathrm{~g}$ of the base ration was added and the flasks were arranged in a water bath (Dubnoff Agi.Orbital SL-158 Solab). The tannin was diluted in heated water $\left(60^{\circ} \mathrm{C}\right)$ and the Monensin in ethanol, as described by Ishlak et al. (2015). Both dilutions were performed under anaerobic conditions one day prior to incubation.

Rumen fluid was obtained from each animal before the morning feeding, filtered through cheesecloth with a pore size of $250 \mu \mathrm{m}$, and stored in insulated thermos without leaving empty spaces, as recommended by Yáñez-Ruiz et al. (2016). The rumen fluid of the three animals was homogenized and filtered to reduce particle contamination and continuously purged under free-oxygen $\mathrm{CO}_{2}$ at $39{ }^{\circ} \mathrm{C}$ during the whole manipulation process. Sequentially, $40 \mathrm{~mL}$ of buffer solution was added to each bottle according to Goering and Van Soest (1970), followed by $10 \mathrm{~mL}$ of rumen fluid, resulting in a rumen fluid: buffer ratio of 1:4 (v/v). Subsequently, $0.2 \mathrm{~mL}$ of the diluent-additive was added to each bottle to achieve the final concentration as previously established. Bottles were immediately sealed with rubber caps and aluminum rings and maintained at $39^{\circ} \mathrm{C}$ in constant agitation. The gas production volume was recorded at 1, 2, 3, 4, 5, 6, $8,10,12,18,24,30,36,42,48,60,72,84$, and $96 \mathrm{~h}$ of incubation, using the semiautomatic reading technique described by Theodorou et al. (1994) and Mauricio et al. (1999)interfaced with a PC allows accumulated head-space gas pressure values to be directly entered into a spreadsheet. These pressure measurements are then used to generate gas volume estimates using a quadratic function derived from simultaneous pressure and volume measurements. Earlier attempts to derive volume from pressure resulted in predicted volume being under estimated. This discrepancy was most likely due to diffusion of head-space gases into the liquid phase, a factor not considered in Boyle's Law, the initial relationship used. In comparison with the syringe technique (Theodorou et al., 1994.

For each in vitro incubation (run), we prepared five glass bottles per treatment, with three bottles to measure gas production over time and two to evaluate in vitro DM digestibility (IVDMD) and in vitro NDF digestibility (IVNDFD) at 48 and $96 \mathrm{~h}$ after the start of the incubation. Three blanks (only ruminal fluid and buffer solution) were also used.

\section{Chemical analysis}

Samples of the ration were processed in a $1 \mathrm{~mm}$ porosity sieve knife mill and the DM, CP, and NDF analysis procedures were performed according to Detmann et al. (2012) (Table 1). At 48 and $96 \mathrm{~h}$ after incubation, two flasks were collected to measure: $\mathrm{pH}, \mathrm{NH}_{3}, \mathrm{VFA}$, IVDMD, and IVNDFD.

To determine $\mathrm{NH}_{3}$ concentration, $2 \mathrm{~mL}$ of each vial were sampled at $48 \mathrm{~h}$, centrifuged at 10000 RPM for 10 minutes at temperature of $4{ }^{\circ} \mathrm{C}$, and stored at $-20^{\circ} \mathrm{C}$ for further analysis according to Chaney and Marbach (1962).

To determine the molar ratios of VFA, aliquots of $0.5 \mu \mathrm{L}$ of the supernatants obtained after centrifugation were injected into the gas chromatograph (Model Shimadzu ${ }^{\circledR}$ GC-2014; Column: VF WAXms-Agilent: $30 \mathrm{~m} \mathrm{x} 0.25 \mathrm{~mm}$ x $0.25 \mu \mathrm{m}$, run time of 14 minutes). Based on the concentrations of acetic, propionic, and butyric acids and the ppm/molar ratio of each acid, the appropriate analyses were performed with $\mathrm{mmol} / \mathrm{L}$ versions.

To evaluate IVDMD and IVNDFD, the withdrawn vials were immediately placed in cold 
water to stop the fermentation. The $\mathrm{pH}$ was measured and the remaining contents of each vial were placed in Ankom ${ }^{\circledR}$ F57 bags (Ankom Technology Corp., Macedon, NY), oven-dried at $105{ }^{\circ} \mathrm{C}$ for $16 \mathrm{~h}$, and weighed. Subsequently, the bags were placed in the Ankom $^{200}$ Fyber Analyzer with neutral detergent solution (VAN SOEST et al., 1991) using a heatstable $\alpha$-amylase, omitting sodium sulfite and kept at $100{ }^{\circ} \mathrm{C}$ for $1 \mathrm{~h}$. The Ankom ${ }^{\circledR}$ F57 bags were then dried in a circulation oven at $55^{\circ} \mathrm{C}$ for $24 \mathrm{~h}$, at 105 ${ }^{\circ} \mathrm{C}$ for $1 \mathrm{~h}$, and weighed.

\section{Calculations and statistical analyses}

The parameters of the dynamics of in vitro gas production over time were estimated using the NLIN procedure of SAS (version 9.3), following the Gompertz function (SCHOFIELD et al., 1994) measured by computer-interfaced pressure sensors, was used to follow the digestion of a crystalline processed cellulose, a bacterial cellulose, and mixtures of these substrates by mixed ruminal bacteria. A first-order, substrate limited model (simple exponential with lag:

$$
\hat{\mathrm{Y}}_{i j k}=\mu+B_{i}+M_{j}+S_{k}+M S_{j k}+\varepsilon_{i j k}
$$

where GP is the cumulative gas production $(\mathrm{mL}), a$ is the theoretical maximum of gas production $(\mathrm{mL})$, $b$ is the maximum gas production rate $\left(\mathrm{mL} \mathrm{h}^{-1}\right)$ that occurs at the point of inflection of the curve, $L$ is the lag time (h) defined as the time-axis intercept of a tangent line at the point of inflection, and $t$ is the incubation time (h). We used the interactive process of the Marquardt algorithm for adjustments.

The variables were analyzed using the MIXED procedure of SAS (version 9.3). Prior to statistical analysis, data of each of the four runs within the same treatment were averaged. Means values of each run were used as the experimental unit (UDÉN et al., 2011). The statistical model included treatments as a fixed factor. Contrasts were generated to compare Monensin with control (without tannin inclusion) and Monensin with tannin levels $(2,4$, and $6 \mathrm{mg} g$ $\left.\mathrm{DM}^{-1}\right)$. Orthogonal contrasts were used to partition specifically the effects of tannin levels $(0,2,4$, and $6 \mathrm{mg} \mathrm{g} \mathrm{DM}^{-1}$ ) on linear and quadratic using the CONTRAST statement of SAS. The LSMEANS option was used to generate individual means for each treatment. In all analyses, significance was declared at $(\mathrm{P}<0.05)$.

\section{Results}

The inclusion of the additives did not affect ( $\mathrm{P}$ $>0.05)$ the kinetic parameters of the fermentation. Tannin reduced $(\mathrm{P}<0.05) \mathrm{GP}$ at $24 \mathrm{~h}$ compared to Monensin (Table 2).

Monensin decreased $(\mathrm{P}<0.05)$ IVDMD at $96 \mathrm{~h}$ and IVNDFD at 48 and $96 \mathrm{~h}$ compared to the control (Table 3). The inclusion of Monensin also reduced $(\mathrm{P}<0.05)$ the IVNDFD at 48 and $96 \mathrm{~h}$ compared to tannin (Table 3 ).

The inclusion of tannin or Monensin did not affect $(\mathrm{P}>0.05)$ the total VFA concentration, and there was also no change $(\mathrm{P}>0.05)$ in the acetate: propionate ratio (Table 4). The $\mathrm{NH}_{3}$ concentration was lower $(\mathrm{P}<0.05)$ with the inclusion of tannin when compared to Monensin (Table 4). There was a quadratic effect $(\mathrm{P}<0.05)$ of tannin in $\mathrm{NH}_{3}$ (Table 4$)$. The $\mathrm{pH}$ was not affected $(\mathrm{P}>0.05)$ by the inclusion of Monensin or tannin in the diets (Table 4).

\section{Discussion}

Changes in ruminal fiber digestion and gas production usually occur as a function of the ability of tannins to form complexes with the protein, with adverse effects on the fermentation process and the production of short chain fatty acids (BUENO et al., 2015)zebu beef cattle (Bos taurus indicus. Commonly, fiber digestibility and gas production are reduced with the inclusion of both condensed and hydrolysable tannin (BHATTA et al., 2009; BUENO et al., 2015;zebu beef cattle (Bos taurus 
indicus FRUTOS et al., 2004) . Possibly, this occurs due to the interference of tannins in cell wall degradation by the inhibition of microbial enzymes and adhesion of fibrolytic populations, thereby decreasing the concentration in gas production of the rumen (BUENO et al., 2015)zebu beef cattle (Bos taurus indicus.

However, the inclusion of tannin did not reduce fiber digestion and thus, the lower gas production observed over a period of $24 \mathrm{~h}$ was not maintained throughout the incubations. A reason for this effect would be the possibility of adaptation of the microorganisms to the presence of the tannins throughout the incubation (ANASSORI et al., 2012).

Ionophores, such as Monensin, change the ion movement across the membranes of grampositive bacteria, altering the proton gradient and $\mathrm{pH}$ within the cell, which results in lysis of the bacteria (MARTIN, 1998). Thus, the growth of gram-positive bacteria is inhibited by Monensin, especially fibrolytic bacteria (e.g. Ruminococcus albus, Ruminococcus flavefaciens, and Butyrivibrio fibrisolvens) (CHEN; WOLIN, 1979), thus causing a reduction in fiber digestibility as observed.

Table 2. In vitro fermentation and total gas production as a function of additive type.

\begin{tabular}{|c|c|c|c|c|c|c|c|c|c|c|}
\hline \multirow[b]{2}{*}{ Variables } & \multicolumn{4}{|c|}{ TANNIN (g/kg DM) } & \multirow[b]{2}{*}{ MON } & \multirow[b]{2}{*}{ SEM $^{d}$} & \multicolumn{4}{|c|}{ CONTRASTS $^{\mathrm{e}}$} \\
\hline & 0 & 2 & 4 & 6 & & & $\begin{array}{c}\mathrm{MON}^{*} \\
0\end{array}$ & $\begin{array}{c}\text { MON* } \\
\text { TAN }\end{array}$ & $\begin{array}{c}\text { TAN } \\
\text { L }\end{array}$ & $\begin{array}{c}\text { TAN } \\
\text { Q }\end{array}$ \\
\hline$a^{a}$ & 142.78 & 143.59 & 141.80 & 141.83 & 139.34 & 2.537 & 0.352 & 0.312 & 0.687 & 0.879 \\
\hline$b^{b}$ & 0.073 & 0.074 & 0.074 & 0.073 & 0.079 & 0.003 & 0.125 & 0.088 & 0.936 & 0.880 \\
\hline$L^{c}$ & 2.27 & 2.32 & 2.34 & 2.38 & 1.96 & 0.249 & 0.405 & 0.206 & 0.755 & 0.975 \\
\hline Gas Production $6 \mathrm{~h}$ & 19.62 & 19.56 & 19.69 & 18.94 & 21.22 & 0.807 & 0.181 & 0.070 & 0.608 & 0.676 \\
\hline Gas Production $12 \mathrm{~h}$ & 41.91 & 42.27 & 42.27 & 41.61 & 44.79 & 1.136 & 0.094 & 0.054 & 0.861 & 0.663 \\
\hline Gas Production $24 \mathrm{~h}$ & 80.78 & 81.30 & 80.46 & 78.58 & 87.12 & 2.194 & 0.059 & 0.014 & 0.461 & 0.593 \\
\hline Gas Production $48 \mathrm{~h}$ & 127.09 & 126.41 & 127.41 & 124.10 & 124.92 & 1.937 & 0.440 & 0.644 & 0.371 & 0.507 \\
\hline Gas Production $72 \mathrm{~h}$ & 139.86 & 140.44 & 139.56 & 137.35 & 139.03 & 2.036 & 0.778 & 0.971 & 0.371 & 0.503 \\
\hline Gas Production $96 \mathrm{~h}$ & 146.24 & 146.88 & 145.81 & 143.83 & 142.32 & 2.477 & 0.281 & 0.282 & 0.466 & 0.604 \\
\hline
\end{tabular}

${ }^{a} a$ is asymptotic gas production $(\mathrm{mL} / \mathrm{g} \mathrm{DM}) ;{ }^{\mathrm{b}} b$ is the rate of digestion $\left(\mathrm{h}^{-1}\right) ;{ }^{\mathrm{c}} \mathrm{L}$ is the Lag time $(\mathrm{h}) .{ }^{\mathrm{d}} \mathrm{SEM}$ is the standard error mean. ${ }^{e}$ Contrasts: MON vs 0 (Monensin vs Substrate without additive); MON vs TAN: (Monensin vs average tannin levels 2, 4, and 6 mg g); TAN L: (Linear tannin 0, 2, 4, and 6), and TAN Q: (Quadratic tannin 0, 2, 4, and 6).

Table 3. In vitro digestibility of DM and NDF as a function of the inclusion of Monensin and tannin content.

\begin{tabular}{|c|c|c|c|c|c|c|c|c|c|c|}
\hline \multirow[b]{2}{*}{ Variables } & \multicolumn{4}{|c|}{ TANNIN (g/kg DM) } & \multirow[b]{2}{*}{ MON } & \multirow[b]{2}{*}{$\mathrm{SEM}^{\mathrm{c}}$} & \multicolumn{4}{|c|}{ CONTRASTS $^{\mathrm{d}}$} \\
\hline & 0 & 2 & 4 & 6 & & & $\begin{array}{c}\mathrm{MON}^{*} \\
0 \\
\end{array}$ & $\begin{array}{c}\text { MON* } \\
\text { TAN }\end{array}$ & TAN L & TAN Q \\
\hline IVDMD $^{\mathrm{a}} 48 \mathrm{~h}$ & 76.00 & 73.68 & 75.21 & 73.73 & 72.85 & 2.185 & 0.325 & 0.600 & 0.596 & 0.850 \\
\hline IVDMD $96 \mathrm{~h}$ & 82.49 & 82.93 & 82.97 & 83.30 & 79.82 & 0.875 & 0.047 & 0.006 & 0.540 & 0.953 \\
\hline IVNDFD $^{\mathrm{b}} 48 \mathrm{~h}$ & 54.18 & 52.35 & 53.15 & 53.22 & 43.58 & 2.387 & 0.007 & 0.004 & 0.850 & 0.698 \\
\hline IVNDFD $96 \mathrm{~h}$ & 73.07 & 73.08 & 72.79 & 72.76 & 69.20 & 0.987 & 0.014 & 0.006 & 0.785 & 0.982 \\
\hline
\end{tabular}

IVDMD ${ }^{\mathrm{a}}$ is the in vitro dry matter digestibility (\%), IVNDFD ${ }^{\mathrm{b}}$ is the in vitro digestibility of neutral detergent fiber (\%), ${ }^{\mathrm{c}} \mathrm{SEM}$ is the standard error mean. ${ }^{\mathrm{d} C o n t r a s t s: ~ M O N ~ v s ~} 0$ (Monensin vs Substrate without additive); MON vs TAN: (Monensin vs average tannin levels 2, 4, and $6 \mathrm{mg} \mathrm{g}$ ); TAN L: (Linear tannin 0, 2, 4, and 6), and TAN Q: (Quadratic tannin 0, 2, 4, and 6). 
Table 4. Effect of the use of Monensin or tannin content on the concentrations of VFA and ammonia and on pH values of the medium fermentation.

\begin{tabular}{|c|c|c|c|c|c|c|c|c|c|c|}
\hline \multirow[b]{2}{*}{ Variables } & \multicolumn{4}{|c|}{ TANNIN (g/kg DM) } & \multirow[b]{2}{*}{ MON } & \multirow[b]{2}{*}{$\mathrm{SEM}^{\mathrm{d}}$} & \multicolumn{4}{|c|}{ CONTRASTS $^{\mathrm{e}}$} \\
\hline & 0 & 2 & 4 & 6 & & & $\begin{array}{c}\text { MON* } \\
0 \\
\end{array}$ & $\begin{array}{c}\text { MON* } \\
\text { TAN }\end{array}$ & TAN L & TAN Q \\
\hline Acetate & 5.30 & 4.96 & 5.00 & 4.91 & 4.77 & 0.576 & 0.530 & 0.788 & 0.673 & 0.825 \\
\hline Propionate & 4.23 & 4.26 & 4.32 & 4.32 & 4.38 & 0.665 & 0.877 & 0.923 & 0.909 & 0.983 \\
\hline Butyrate & 3.73 & 3.90 & 4.07 & 4.23 & 4.23 & 0.964 & 0.720 & 0.885 & 0.709 & 0.991 \\
\hline Acetate: Propionate & 1.26 & 1.18 & 1.18 & 1.16 & 1.13 & 0.104 & 0.380 & 0.722 & 0.518 & 0.755 \\
\hline VFA Total $^{a}$ & 13.26 & 13.12 & 13.39 & 13.46 & 13.38 & 2.056 & 0.967 & 0.981 & 0.925 & 0.960 \\
\hline $\mathrm{NH}_{3}-\mathrm{N}^{\mathrm{b}}$ & 14.41 & 12.17 & 12.76 & 12.97 & 15.12 & 0.349 & 0.171 & $<0.001$ & 0.030 & 0.003 \\
\hline $\mathrm{pH}^{\mathrm{c}} 48$ & 6.58 & 6.59 & 6.64 & 6.67 & 6.63 & 0.102 & 0.709 & 0.978 & 0.491 & 0.971 \\
\hline pH 96 & 6.64 & 6.63 & 6.64 & 6.62 & 6.60 & 0.052 & 0.604 & 0.630 & 0.818 & 0.914 \\
\hline
\end{tabular}

${ }^{\mathrm{a}}$ VFA is the volatile fatty acids (mmol/L); ${ }^{\mathrm{N}} \mathrm{NH}_{3} \mathrm{~N}$ is the ammoniacal nitrogen (mg/dL); ${ }^{\mathrm{p} H} 48$ and 96 is the $\mathrm{pH}$ at 48 and 96 hours; ${ }^{\mathrm{d} S E M}$ : Standard error mean. ${ }^{\mathrm{e}}$ Contrasts: MON vs 0 (Monensin vs Substrate without additive); MON vs TAN: (Monensin vs average tannin levels 2, 4, and $6 \mathrm{mg} \mathrm{g}$ ); TAN L: (Linear tannin 0, 2, 4, and 6), and TAN Q: (Quadratic tannin 0, 2, 4, and 6).

The reduction in fiber digestion may cause an alteration in the production of VFA's, especially acetate, altering the acetate: propionate ratio (BUENO et al., 2015)zebu beef cattle (Bos taurus indicus. Although a lower digestibility of NDF was observed with Monensin, no differences were found for VFA. In addition, gas production is an indicative of the quantitative production of VFA (KIM et al., 2014)each surgically fitted with a ruminal cannula, consuming 0.50 alfalfa cubes and 0.50 cracked cornbased concentrate at 1.75 ??NEm requirements were used as rumen fluid donors. For both experiments in vitro gas production was measured in a completely random design with a 3??2??3 factorial treatment structure. Factors were diet [control (no substrate. Therefore, as gas production was similar between additives, the absence of effects on VFA could also be expected.

Considering the lower $\mathrm{NH}_{3}$ concentrations obtained with tannin, it is suggested that lower levels of protein were degraded in the medium, as a result of tannin affinity for the protein. Additionally, condensed tannins may inhibit the activity of protozoa that degrade proteolytic bacteria (BHATTA et al., 2009; MCMAHON et al., 1999). This mode of action against microorganisms is still not well understood (BODAS et al., 2012). In this sense, it remains to be determined whether the reduction in protein use associated with tannin is a result of protein protection or direct inhibition of proteolytic bacteria (MCMAHON et al., 1999).

Although the concentration of $\mathrm{NH}_{3}$ was lower at all levels of tannin inclusion, it was observed that the lower concentration was obtained with the lower dose used and that as the tannin inclusion was increased, the $\mathrm{NH}_{3}$ concentration also increased. This demonstrates that there may be other mechanisms involved besides the affinity between tannins and protein.

In addition, factors such as ration composition, adaptation period and exposure to the product, the way the samples were collected, the type and concentrations of the additives in the rations (BODAS et al., 2012; GETACHEW et al., 2008; MCGUFFEY et al., 2001), and the donor animal of the inoculum (BUENO et al., 2015; FRUTOS et al., 2004)zebu beef cattle (Bos taurus indicus are probably related to the variability of the literature 
results regarding the effects of Monensin and tannin on the digestibility of DM, NDF, and proportions of VFA and $\mathrm{NH}_{3}$.

\section{Conclusion}

The inclusion of tannin in vitro reduced the $\mathrm{NH}_{3}$ concentration at all the dosages used, being more considerably when used in low dose. In vivo studies are needed to validate these effects.

\section{References}

ANASSORI, E.; DALIR-NAGHADEH, B.; PIRMOHAMMADI, R.; TAGHIZADEH, A.; ASRIREZAEI, S.; FARAHMAND-AZAR, S.; BESHARATI, M.; TAHMOOZI, M. In vitro assessment of the digestibility of forage based sheep diet, supplemented with raw garlic, garlic oil, and monensin. Veterinary Research Forum, Urmia, v. 3, n. 1, p. 5-11, 2012.

BHATTA, R.; UYENO, Y.; TAJIMA, K.; TAKENAKA, A.; YABUMOTO, Y.; NONAKA, I.; ENISHI, O.; KURIHARA, M. Difference in the nature of tannins on in vitro ruminal methane and volatile fatty acid production and on methanogenic archaea and protozoal populations. Journal of Dairy Science, Madison, v. 92, n. 11, p. 55125522, 2009. DOI: $10.3168 /$ jds.2008-1441

BODAS, R.; PRIETO, N.; GARCÍA-GONZÁLEZ, R.; ANDRÉS, S.; GIRÁLDEZ, F. J.; LÓPEZ, S. Manipulation of rumen fermentation and methane production with plant secondary metabolites. Animal Feed Science and Technology, London, v. 176, n. 1-4, p. 78-93, 2012. DOI: 10.1016/j.anifeedsci.2012.07.010

BUENO, I. C. S.; BRANDI, R. A.; FRANZOLIN, R.; BENETEL, G.; FAGUNDES, G. M.; ABDALLA, A. L.; LOUVANDINI, H.; MUIR, J. P. In vitro methane production and tolerance to condensed tannins in five ruminant species. Animal Feed Science and Technology, London, v. 205, n. 1, p. 1-9, 2015. DOI: 10.1016/j. anifeedsci.2015.03.008

CHANEY, A. L.; MARBACH, E. P. Modified reagents for determination of urea and ammonia. Clinical Chemistry, Washington, v. 8, n. 2, p. 130-132, 1962.

CHEN, M.; WOLIN, M. J. Effect of monensin and lasalocid-sodium on the growth of methanogenic and rumen saccharolytic bacteria. Applied Environmental Microbiology, v. 38, n. 1, p. 72-77, 1979. DOI: 00992240/79/07-0072/06\$02.00/0
CIESLAK, A.; ZMORA, P.; PERS-KAMCZYC, E.; SZUMACHER-STRABEL, M. Effects of tannins source (Vaccinium vitis idaea L.) on rumen microbial fermentation in vivo. Animal Feed Science and Technology, London, v. 176, n. 1-4, p. 102-106, 2012. DOI: 10.1016/j.anifeedsci.2012.07.012.

DETMANN, E.; SOUZA, M. A.; VALADARES FILHO, S. C.; QUEIROZ, A. C.; BERCHIELLI, T. T.; SALIBA, E. O. S.; CABRAL, L. S.; PINA, D. S .; LADEIRA, M. M.; AZEVEDO, J. A. G. Métodos para análise de alimentos. Visconde do Rio Branco:Suprema, 2012.

DINIUS, D. A.; SIMPSON, M. E.; MARSH, P. B. Effect of monensin fed with forage on digestion and the ruminal ecosystem of steers. Journal of Animal Science, Champaign, v. 42, n. 1, p. 229-234, 1976.

FRUTOS, P.; HERVÁS, G.; GIRÁLDEZ, F. J.; MANTECÓN, A. R. An in vitro study on the ability of polyethylene glycol to inhibit the effect of quebracho tannins and tannic acid on rumen fermentation in sheep, goats, cows, and deer. Australian Journal of Agricultural Research, v. 55, n. 11, p. 1125-1132, 2004. DOI: 10.1071/ $\operatorname{ar} 04058$

GETACHEW, G.; PITTROFF, W.; PUTNAM, D. H.; DANDEKAR, A.; GOYAL, S.; DEPETERS, E. J. The influence of addition of gallic acid, tannic acid, or quebracho tannins to alfalfa hay on in vitro rumen fermentation and microbial protein synthesis. Animal Feed Science and Technology, London, v. 140, n. 3-4, p. 444-461, 2008. DOI: 10.1016/j.anifeedsci.2007.03.011

GOERING, M. K.; VAN SOEST, P. J. Forage fiber analysis (apparatus, reagents, procedures and some applications). In: GOERING, M. K.; VAN SOEST, P. J. Agriculture handbook. Washington: Ed. Agricultural Research Service, USDA, 1970, n. 379, p. 1-20.

ISHLAK, A.; GUNAL, M.; ABUGHAZALEH, A. A. The effects of cinnamaldehyde, monensin, and quebracho condensed tannin on rumen fermentation, biohydrogenation, and bacteria in continuous culture system. Animal Feed Science and Technology, London, v. 207, p. 31-40, 2015. DOI: 10.1016/j. anifeedsci.2015.05.023

KIM, D. H.; MIZINGA, K. M.; KUBE, J. C.; FRIESEN, K. G.; MCLEOD, K. R.; HARMON, D. L. Influence of monensin and lauric acid distillate or palm oil on in vitro fermentation kinetics and metabolites produced using forage and high concentrate substrates. Animal Feed Science and Technology, London, v. 189, p. 19-29, 2014. DOI: 10.1016/j.anifeedsci.2013.12.010

MAKKAR, H. P. S.; SEN, S.; BLUMMEL, M.; BECKER, K. Effects of fractions containing Saponins 
from Yucca schidigera, Quillaja saponaria, and Acacia auriculoformis on Rumen Fermentation. Journal of Agricultural and Food Chemistry, Washington, v. 46, n. 10, p. 4324-4328, 1998. DOI: 10.1021/jf980269q

MARTIN, S. A. Manipulation of ruminal fermentation with organic acids: a review. Journal of Animal Science, Champaign, v. 76, n. 12, p. 3123-3132, 1998. DOI: $10.2527 / 1998.76123123 x$

MAURICIO, R. M.; MOULD, F. L.; DHANOA, M. S.; OWEN, E.; CHANNA, K. S.; THEODOROU, M. K. A semi-automated in vitro gas production technique for ruminant feedstuff evaluation. Animal Feed Science and Technology, Amsterdam, v. 79, n. 4, p. 321-330, 1999. DOI: 10.1016/S0377-8401(99)00033-4

MCGUFFEY, R. K.; RICHARDSON, L. F.; WILKINSON, J. I. D. Ionophores for dairy cattle: current status and future outlook. Journal of Dairy Science, Madison, v. 84, E194-E203, 2001. DOI: 10.3168/jds. S0022-0302(01)70218-4

MCMAHON, L. R.; MCALLISTER, T. A.; BERG, B. P.; MAJAK, W.; ACHARYA, S. N.; POPP, J. D.; COULMAN, B. E.; WANG, Y.; CHENG, K. J. A review of the effects of forage condensed tannins on ruminal fermentation and bloat in grazing cattle. Canadian Journal of Plant Science, v. 80, n. 3, p. 469-485, 1999. DOI: $10.4141 /$ P99-182

MEZZOMO, R.; PAULINO, P. V. R.; DETMANN, E; VALADARES FILHO, S. C.; PAULINO, M. F.; MONNERAT, J. P. I. S.; DUARTE, M. S.; SILVA, L. H. P.; MOURA, L. S. Influence of condensed tannin on intake, digestibility, and efficiency of protein utilization in beef steers fed high concentrate diet. Livestock Science, v. 141, n. 1, p. 1-11, 2011. DOI: 10.1016/j. livsci.2011.04.004

RUSSELL, J. B.; STROBEL, H. J. Effect of ionophores on ruminal fermentation. Applied Environmental Microbiology, Washington, v. 55, n. 1, p. 1-6, 1989. DOI: 0099-2240/89/010001-06\$02.00/0

SCHOFIELD, P.; PITT, R. E.; PELL, A. N. Kinetics of fiber digestion from in-vitro gas-production. Journal of Animal Science, Champaign, v. 72, n. 11, p. 2980-2991, 1994. DOI: $10.2527 / 1994.72112980 x$
STATISTICAL ANALYSIS SYSTEM INSTITUTE SAS. The SAS System, release 9.3. SAS Institute Inc., Cary: NC, 2016.

TEDESCHI, L. O.; CALLAWAY, T. R.; MUIR, J. P.; ANDERSON, R. C. Potential environmental benefits of feed additives and other strategies for ruminant production. Revista Brasileira de Zootecnia, Viçosa, v. 40, n. 9, p. 291-309, 2011. DOI: 10.1590/S0100204X2014000900009

THEODOROU, M. K.; WILLIAMS, B. A.; DHANOA, M. S.; MCALLAN, A. B.; FRANCE, J. A simple gas production method using a pressure transducer to determine the fermentation kinetics of ruminant feeds. Animal Feed Science and Technology, Amsterdam, v. 48, n. $3-4$, p. 185-197, 1994. DOI: 10.1016/03778401(94)90171-6

UDÉN, P.; ROBINSON, P. H.; MATEOS, G. G.; BLANK, R. Use of replicates in statistical analyses in papers submitted for publication in Animal Feed Science and Technology. Animal Feed Science and Technology, Amsterdam, v. 171, p. 1-5, 2011. DOI: 10.1016/j. anifeedsci.2011.10.008

VAN SOEST, P. J.; ROBERTSON, J. B.; LEWIS, B. A. Methods for dietary fiber, neutral detergent fiber, and nonstarch polysaccharides in relation to animal nutrition. Journal of Dairy Science, Madison, v. 74, n. 10, p. 35833597, 1991.

WAGHORN, G. C.; JOHN, A.; JONES, W. T.; SHELTON, I. D. Nutritive value of Lotus corniculatus L. containing low and medium concentrations of condensed tannins for sheep. Proceedings of the New Zealand Society of Animal Production, v. 47, n. 1, p. 25-30, 1987.

YÁÑEZ-RUIZ, D. R.; BANNINK, A.; DIJKSTRA, J.; KEBREAB, E.; MORGAVI, D. P.; O’KIELY, P.; REYNOLDS, C. K.; SCHWARM, A.; SHINGFIELD, K. J.; YU, Z.; HRISTOV, A. N. Design, implementation, and interpretation of in vitro batch culture experiments to assess enteric methane mitigation in ruminants-a review. Animal Feed Science and Technology, London, v. 216, p. 1-18, 2016. DOI: 10.1016/j.anifeedsci.2016.03.016 
